\title{
KILLING AND BLOODY SUNDAY, NOVEMBER 1920
}

\author{
ANNE DOLAN \\ Trinity College, Dublin
}

\begin{abstract}
A B S TRACT. 2I November 1920 began with the killing of fourteen men in their flats, boarding houses, and hotel rooms in Dublin. The Irish Republican Army (IRA) alleged that they were British spies. That afternoon British forces retaliated by firing on a crowd of supporters at a Gaelic football match in Croke Park, killing twelve and injuring sixty. The day quickly became known as Bloody Sunday. Much has been made of the afternoon's events. The shootings in Croke Park have acquired legendary status. Concern with the morning's killing has been largely limited to whether or not the dead men were the spies the IRA said they were. There has been little or no consideration of the men who did the killing. This article is based on largely unused interviewes and statements made by the IRA men involved in this and many of the other days that came to constitute the guerrilla war fought against the British forces in Ireland from Fanuary IgIg until Fuly I92I. This morning's killings are a chilling example of much of what passed for combat during this struggle. Bloody Sunday morning is used here as a means to explore how generally young and untrained IRA men killed and how this type of killing affected their lives.
\end{abstract}

Lieutenant Frank Teeling shot a man on 27 March i923. Admittedly, in the closing weeks of the Irish civil war this was not an unusual thing for a Free State soldier to do. But the man Frank Teeling shot was not a republican. William Johnson was a member of the Citizens' Defence Force and he was shot because he brought a bag of tomatoes into the bar at the Theatre Royal. ${ }^{1}$ Frank Teeling was drunk, drunk to the point of being served nothing stronger than ginger beer. For some reason he took exception to the tomatoes; he threw them on the ground; guns were drawn and Johnson was dead. At his trial Teeling claimed he had acted in self-defence. The jury concurred with the judge that 'through drink he had allowed his mind to be dethroned', found him guilty of manslaughter instead of murder, and recommended mercy 'on account of the state of his mind'. ${ }^{2}$ Teeling was jailed for eighteen months. ${ }^{3}$

It may be enough to put all this down to a heady combination of drink, revolvers and the stress of civil war. But there was a little more to Teeling's case

Department of History, School of Histories and Humanities, Trinity College, Dublin, Dublin 2 adolan@tcd.ie

1 The Citizens' Defence Force was a plain-clothes group attached to the Criminal Investigation Department during the civil war. Made up of armed men, it was used for patrolling and gathering intelligence. See Eunan O'Halpin, Defending Ireland: the Irish state and its enemies since 1922 (Oxford, I999), pp. I2-I3. $\quad{ }^{2}$ Irish Times, I9 Apr. I923. $\quad{ }^{3}$ After serving his sentence he emigrated to Canada. 
than met the eyes of the judge and jury at his speedily expedited trial. Eight days before the shooting, the Department of Finance had made out a cheque for £250 to Lieutenant Frank Teeling. ${ }^{4}$ It had done so because the National Army wanted Teeling to disappear. He had, in the commander-in-chief's opinion, been 'publicly misconducting' himself, 'bringing serious discredit on us'. It was thought best to send him to Australia with $£ 500$ and to convince him that it would be a particularly bad idea ever to come back. ${ }^{5}$ Though it halved the grant, the Executive Council heartily approved of the plan. It was even gracious enough to suggest that given the condition of the labour market in Australia another destination should be considered. ${ }^{6}$ This was transportation Free State style. Though one can wonder about Teeling's fate if he had cashed the cheque and gone, about the life that William Johnson never got to lead because Teeling stayed, there is something more fascinating still about the offer itself. In March I923 there seemed little shortage of soldiers 'publicly misconducting' themselves, yet few were presented with the prospect of a new life abroad with $f 25^{\circ}$ in hand. Teeling was considered an exceptional case because every member of the Executive Council was well aware of what was termed 'his past services to the state'. 7 They all knew what Frank Teeling had done, what he had suffered for Ireland; they all knew that on 2 I November I920 he had stood with four other men at the bottom of a British soldier's bed and shot him until he was dead.

It could be argued that there is little or no connection between Teeling's whereabouts on Bloody Sunday morning I920 and the shooting in the Theatre Royal almost two and a half years later. Indeed a whole series of events both before and in between these two dates may have brutalized Teeling to the point where he could simply kill a man for no apparent reason. Teeling had learned to kill without question for his cause: that was his 'past service to the state'. And while the offer of the money and the second chance may have acknowledged his efforts, the desire to get rid of him seemed to accept that this man no longer wanted, or knew how, to stop. Teeling may seem like an extreme example; in much the same way, Bloody Sunday is quite unlike any other day in the Irish revolution's calendar. It was one of the most violent and dramatic to date in a war that had been wilfully declared by the murder of two Royal Irish Constabulary men in Soloheadbeg, Co. Tipperary, almost two years before. 2I November began with the execution of fourteen men in their flats, boarding houses, and hotels in Dublin. The Irish Republican Army (IRA) called their victims spies; the British authorities called them court martial officers and claimed that the

\footnotetext{
${ }^{4}$ Memorandum by Michael MacDunphy, 23 May 1936, Dublin, National Archives (Dublin NA), Department of the Taoiseach (D/T) s2 I66.

${ }^{5}$ Letter from Richard Mulcahy, commander-in-chief, to W. T. Cosgrave, president of the Executive Council, 5 Feb. I923, ibid.; Eunan O'Halpin, 'British intelligence in Ireland, I9I4-I92I', in Christopher Andrew and David Dilks, eds., The missing dimension: governments and intelligence communities in the twentieth century (London, I984), pp. 54-77, at p. 26I.

${ }^{6}$ Extract from the Minutes of the Executive Council C.I/56, 5 Mar. I923, Dublin NA D/T s2 I66.

7 Ibid.
} 
IRA killed them to protect their captured brethren and themselves from the full rigours of the law. Reprisals followed in Croke Park that afternoon, where Auxiliaries fired on a crowd of Gaelic football supporters, killing twelve and injuring sixty. And that evening three prisoners were also killed: Dick McKee and Peadar Clancy were both heavily involved in the planning of the morning's executions, but Conor Clune, visiting Dublin from Co. Clare, was said at the time, and since, to be just an innocent abroad in the wrong place at the wrong time. Shot while trying to escape from Dublin Castle was the euphemistic explanation of their fate.

History has seemed more concerned with the afternoon's events. Shooting unarmed football supporters is the stuff nationalist mythology is made of, particularly when the British authorities disputed who fired in Croke Park first. The morning's events have been left to those concerned with spies and spying, to those who consider the killings largely in terms of their effects on British intelligence. It has been established that mistakes were made, that some were not the spies they were purported to be, and the accusation is made more pointed by the unprecedented parade of the dead to Westminster Abbey with its resonant associations with the body of the Unknown Warrior who had been honoured there fifteen days before. ${ }^{8}$ However, in the midst of these and other concerns, the morning's killers have been largely ignored. Yet both Bloody Sunday morning and men like Frank Teeling are a vital means to understand a certain kind of killing: to understand how men killed at close range and how they felt about what they had done. Much has been written about the effects of killing on soldiers in conventional armies, in more conventional battle situations, particularly by Joanna Bourke and Samuel Hynes in the context of the Great War, the Second World War, Korea, and Vietnam, but there is no real consideration of killing and its effects on a band of largely untrained young men in a guerrilla war. ${ }^{9}$ Unlike many of the theatres of conflict in the Great War, for instance, where, as Joanna Bourke has noted, "many servicemen never saw "the enemy", where often 'injuries were not even usually caused by another identifiable individual', killing in Ireland in the I9I9-2I period regularly took the form of executions and assassinations. ${ }^{10}$ IRA men stood close to their victims, watched their restraint or their panic, the expression on their faces as they died. In their guerrilla war there was little opportunity and fewer resources to fight any other way. Although there are points of comparison with Bourke's work on face-to-face killing from the Great War to Vietnam, the conditions of Bloody Sunday's killings were quite distinct. ${ }^{11}$ This was face-to-face killing where the battlefield was a bedroom, where combat took the form of assassination, where the army was nothing more

8 Times, 25 Nov. 1920; Joanna Bourke, Dismembering the male: men's bodies, Britain and the Great War (London, I999 edn), p. 210.

${ }^{9}$ Joanna Bourke, An intimate history of killing: face-to-face killing in twentieth-century warfare (London, I999); Samuel Hynes, The soldiers' tale: bearing witness to modern war (London, 1998).

${ }_{10}$ Bourke, Dismembering the male, pp. $4^{2-3} . \quad{ }^{11}$ Bourke, An intimate history of killing. 
than a band of very young men, without uniforms and often the training to use the weapons in their hands. 'This Irish St Bartholomew' as Sir Nevil Macready, commander of the British forces in Ireland, labelled Bloody Sunday morning, exemplifies this type of face-to-face killing at its very extreme. ${ }^{12}$ Perhaps the most disturbing part of the study of guerrilla war in Ireland at this time is that neither Frank Teeling nor Bloody Sunday are that unusual at all.

\section{I}

Doors were opened by arrangement or by force at 9 o'clock on Bloody Sunday morning. Within minutes nineteen men had been shot; five of them wounded, fourteen dead. But it did not stop there. That night in Dublin Castle, an Auxiliary Cadet, Henry Spenle, shot himself in the head. Witnesses testified to Spenle's 'deep depressions' since the Great War, but blamed 'the happenings of the morning which he had been discussing', that they 'preyed on his mind'. ${ }^{13}$ On 9 December Colonel Hugh Ferguson Montgomery died from the wounds he had received eighteen days before. ${ }^{14}$ The last to die was a wife who had seen her husband killed. She had lived for three weeks haunted by the sound of shooting, of gunmen laughing, by the memory of a man washing her husband's blood off his hands in her own sink. She died giving birth to a still-born child. ${ }^{15}$ But the IRA had meant to kill more. Other houses and hotels were visited that morning. The lucky ones escaped or had already changed addresses; others had just gone out, some had not returned from wherever they had been the night before. Yet even this was all a mere shadow of more ambitious intentions. For months names were added and subtracted from a list of what became known as the 'particular ones' ${ }^{16}$ Michael Collins's own phrase for the members of the new British spy ring rumoured to have come to Dublin to grasp, as Lloyd George instructed, the Irish 'murder gang' by the throat. ${ }^{17}$ Snatches of information from maids and porters and wastepaper baskets, times of comings and goings, places with lights on after curfew; all manner of whispers and overhearings turned themselves into dossiers and reports. ${ }^{18}$ The simplest things were noted: who wore a signet ring

12 Sir Nevil Macready, Annals of an active life, II (London, I924), p. 509.

13 Proceedings of a court of inquiry in lieu of inquest on Henry E. Spenle, London, National Archives (London NA) WO 35/159B.

${ }_{14}$ Mark Sturgis's Diary Part II, Io Dec. I920, London NA 30/59/2.

15 Anonymous, An officer's wife in Ireland (London and Dublin, I994 edn), p. 7I; J. M. Nankivell and S. Loch, Ireland in travail (London, I922), pp. 98-9.

16 The phrase Michael Collins used in his instructions to Peadar Clancy quoted in Calton Younger, Ireland's civil war (New York, I969 edn), p. I I4. They were also described as the 'special ones' by Liam Tobin, Ernie O’Malley notebooks, University College, Dublin Archives Department (UCDA) pi7b/ IOO(III).

17 Speech by David Lloyd George at the Guildhall banquet, 9 Nov. I920, quoted in Mark Pottle, ed., Champion redoubtable - the diaries and letters of Violet Bonham Carter, I9I4-I945 (London, I998), p. II7.

18 See for example Charles Dalton, Bureau of Military History (BMH) Witness Statement (WS) 434 and Frank Thornton, BMH WS 6i5. 
on one of his left fingers, who wore a grey or a black or a navy suit; which one had a girlfriend in a flat above a billiard hall, which one might talk if he got a little drunk. ${ }^{19}$ There were suspicions and confirmations, a face associated with the killing of John Lynch in his hotel bedroom; a source prepared to swear that another tortured Kevin Barry. ${ }^{20}$ There were rumours about a Cairo Gang; talk of secret missions in the Great War, stories of dastardly achievements in foreign fields, of Britain's finest spies coming closer, ever closer, all the time becoming a case of them or us.

This is the familiar version of events, at least the version that predominates in many of the Bureau of Military History statements and Ernie O'Malley's interviews with IRA men involved. ${ }^{21}$ The dull refrain that it needed to be done, that they had to be stopped, that they were all spies, that there were no mistakes, comes again and again with dreary repetition. Most is said about why it was done, about the rightness of it being done, about the care and attention that went into proving every case against each man, of proving each one to be what their brutal murders necessitated them to be - just vile English spies. ${ }^{22}$ IRA statements condemned the dead men thus: 'they were the murder gang. They were capable of murder certainly and there was a story that some had seen foreign service. ${ }^{\mathbf{2 3}}$ They were the 'cream of British Military Intelligence'; spies 'disguised as civilians ... liable to the death penalty' like any others of their kind.$^{24}$ For many they must have been guilty because they supposed that 'the proof had to be a full IOO \% watertight before any action could be taken' by the IRA. ${ }^{25}$ And the IRA could count on a degree of trust; they were 'good men and they wouldn't kill any innocent people'. ${ }^{26}$ The killings may have been 'Dreadful! Horrible!', but the same person was sure: 'I have no doubt they deserved it. ${ }^{27}$ Enough people believed there was no smoke without fire. But this retreat to explanations makes perfect sense. Although Todd Andrews revelled in the fact that the British

19 Rex Taylor, Michael Collins (London, I96i edn), p. I04; Piaras Béaslaí, 'Fourteen British officers and agents executed in Dublin on "Bloody Sunday", in With the IRA in the fight for freedom IgI9 to the Truce: the red path of glory (Tralee, n.d.), pp. II4-I9, at p. i i7; Charles Dalton, Ernie O'Malley notebooks, UCDA pi7b/i22(20); Richard Bennett, The Black and Tans (Staplehurst, $200 \mathrm{I}$ edn), p. I20.

${ }^{20}$ Macready, Annals of an active life, p. 508; Pat McCrea, BMH WS 4I3; Lynch was a Sinn Féin official killed in his room in the Exchange Hotel. It was believed to be a case of mistaken identity, his killers believing him to be the Cork IRA man, Liam Lynch. Kevin Barry was the eighteen-year-old medical student executed for his part in an ambush at Monk's Bakery in Dublin where three soldiers were fatally wounded.

21 The Bureau of Military History was established in January 1947 by the minister for defence, Oscar Traynor. In its lifetime it collected I,I73 statements from men and women involved in the independence struggle from I9I3 to I92I. The Ernie O'Malley notebooks consist of notes of interviews which O'Malley undertook with c. 400 veterans of the I9I3-23 period.

${ }^{22}$ See for example Donal O'Kelly, 'The Dublin scene: war amid the outward trappings of peace', in With the IRA, pp. 25-30.

${ }^{23}$ Liam Tobin, Ernie O’Malley notebooks, UCDA pizb/ıoo(III).

${ }^{24}$ O'Kelly, 'The Dublin scene', p. 29; Béaslaí, 'Fourteen British officers', p. i I7.

25 Frank Thornton, BMH WS 6i5.

${ }^{26}$ Quoted in Kevin A. Kearns, Dublin tenement life: an oral history (London, 2000 edn), p. 85.

27 Nankivell and Loch, Ireland in travail, p. 95. 
press 'sucked Roget's Thesaurus dry to find words to denounce us. We were gunmen, terrorists, extremists, murderers, assassins, butchers, thugs'; such bravado possibly came more easily to Andrews when writing his memoirs fiftynine years after the event. ${ }^{28}$ 'Murderer' was the word that seemed to rankle most; the only moniker that Collins was said to resent. ${ }^{29}$ Lloyd George may have pronounced that the fourteen dead 'got what they deserved, beaten by counterjumpers', Churchill may have thought them 'careless fellows' who 'ought to have taken precautions, ${ }^{30}$ but nevertheless Collins still penned a remarkable defence of his actions in case the question of Bloody Sunday arose at the treaty negotiations in London in December I921.

My one intention was the destruction of the undesirables who continued to make miserable the lives of ordinary decent citizens. I have proof enough to assure myself of the atrocities which this gang of spies and informers have committed. Perjury and torture are words too easily known to them. If I had a second motive it was no more than a feeling such as I would have for a dangerous reptile. By their destruction the very air is made sweeter. That should be the future's judgment on this particular event. For myself, my conscience is clear. There is no crime in detecting and destroying in war-time, the spy and the informer. They have destroyed without trial. I have paid them back in their own coin. ${ }^{31}$

He is quoted, albeit to less colourful effect, by General Crozier, by Hayden Talbot, by any who claim to have discussed his methods and motives on Bloody Sunday with him before his death. ${ }^{32}$ But it was easy for Collins to talk in terms of dangerous reptiles and sweeter air. He was elsewhere on Bloody Sunday morning. He was not pointing a gun at a man shivering in his bed. Whatever thoughts and images and descriptions of these fourteen dead officers Collins cared to conjure with, the circumstances of the deaths would always undo his careful preparations. Shooting a detective on the street, on his way to or from Dublin Castle, even on his way to church, had become a relatively familiar type of brutality. At least the prey was armed, he had some chance; and as time went on he may have come to expect it; he often wore a 'steel waistcoat', he sometimes walked different routes to his work. But some hierarchy of horror had been grossly breached on Bloody Sunday morning. It was one thing to gun down a man in cold blood in the street. It was quite another to barge into his bedroom, to shoot him where he lay, in front of his wife, within hearing of his child. That nine of the men killed wore only their pyjamas seemed to tip the scales of horror even further still. ${ }^{33}$ There was the added indignity of not even being properly dressed. It was for these reasons that Larry Nugent was so insistent in his Bureau statement that it was not murder, that 'it was an act of war duly carried out under orders ... [that] the life of every IRA man in Dublin was at stake', ${ }^{34}$ why Frank

28 C. S. Andrews, Dublin made me (Dublin, I979), p. I55.

29 Taylor, Collins, p. $96 . \quad 30$ Ibid., p. Io6.

31 Ibid.

32 Brigadier General F. P. Crozier, Ireland for ever (London, I932), pp. 215-27; Hayden Talbot, Michael Collins' own story (London, I923), pp. 93-4. $\quad{ }^{33}$ Anon., An officer's wife, p. 70.

${ }^{34}$ Larry Nugent, BMH WS 907. 
Thornton kept insisting, even at lectures to young army cadets in r940 that 'that morning was one of the most critical ones in the history of our movement', that, as he said, 'all jobs were executed' even when they were not. ${ }^{35}$ 'The British Secret Service was wiped out on the 2ist November 1920. '36 That was the story and the brutality of the day meant that most of the men involved were going to stick to it.

Most who have written about Bloody Sunday since have stuck to it too. Tim Pat Coogan was happy to recount the participants' traditional version of events: 'The sounds of Dublin's mass bells were suddenly punctuated by staccato bursts of shooting as Collins' men crippled the entire British Secret Service operation in Ireland. ${ }^{37}$ The newest edition of James Gleeson's Bloody Sunday is prefaced with the claim that it was the day 'most responsible for the existence of the Irish Republic' ${ }^{38}$ At the other end of the historiographical scale, Peter Hart's consideration of IRA violence, The IRA at war, I9I6-I923, has taken little or no account of the day's events, despite the fact that it was possibly the largest single IRA initiative in Dublin. ${ }^{39}$ It has come to be considered an exception, a one-off, a 'coup de théatre', bloody and spectacular, but with little to tell about the IRA. ${ }^{40}$ What brief spells of interest there were in Bloody Sunday in the I970s seem preoccupied with British spies and the state of British intelligence, largely indifferent to the consideration of anything else. Whether the men who were shot were or were not the spies they were reported to be has been outlined by Tom Bowden and largely refuted in nine pages by Charles Townshend. ${ }^{41}$ That their deaths did not cripple British intelligence in Ireland has been proved conclusively by British records and reports released since. ${ }^{42}$ But in some senses it is largely irrelevant if Townshend contradicts Bowden. What matters, in the context of this article, is what the men sent to do the killing believed and needed to believe about the men they shot. The dead had to be spies because if they

35 'Account of IRA intelligence during the Anglo-Irish War given by Captain Frank Thornton to Army units', I940[?], Military Archives, A/o80o/IV. He reiterates this exact phrase in his Bureau of Military History statement, WS 6I5. 36 Ibid.

37 Tim Pat Coogan, De Valera: long fellow, long shadow (London, I993), p. I9o. This echoes David Neligan's view that 'the whole spy network was paralyzed, and I don't they ever fully recovered from this blow' in Kenneth Griffith and Timothy O'Grady, eds., Ireland's unfinished revolution: an oral history (Colorado, I999 edn), p. I76. Also Frank Gallagher's assessment that 'The British Intelligence service never recovered from that blow'. David Hogan [Frank Gallagher's pseudonym], The four glorious years (Dublin, I953), p. 243 .

38 Dermot McEvoy, 'Introduction', in James Gleeson, Bloody Sunday (Connecticut, 2004 edn), pp. xvii-xx, at p. xvii. $\quad{ }^{39}$ Peter Hart, The IRA at war, I9I6-I923 (Oxford, 2003).

40 Alvin Jackson, Ireland, I798-1998 (Oxford, I999), p. 249.

41 Tom Bowden, 'Bloody Sunday - a reappraisal', European Studies Review, 2 (Jan. I972), pp. 25-42; idem, 'The Irish underground and the war of independence, I919-1921', Fournal of Contemporary History, 8 (Apr. I973), pp. 3-23; idem, The breakdown of public security (London, I977); Charles Townshend, 'Bloody Sunday - Michael Collins speaks', European Studies Review, 9 (July 1979), pp. 377-85.

${ }^{42}$ Peter Hart, ed., British intelligence in Ireland, 1920-192I: the final reports (Cork, 2002); Eunan O'Halpin, 'What the British knew', Dublin Review, 8 (Autumn 2002), pp. I09-I4, at p. II2; idem, 'British intelligence', pp. 54-77. 
were not, then their killers were the murderers and assassins that British propaganda always said they were. They had to be spies; there were no mistakes, because otherwise how could these men justify what they had done. It had to be a coup for IRA intelligence with never any admission of mistakes. For most of the men involved the myth of Bloody Sunday morning needed to remain in place. That is why these pages are grounded in what these men said or wrote themselves. Their words are often confused and contradictory. There are often conflicting statements about the same events. But in the case of many of the quotations used in this article, much of their value is in manner of the telling; the confusion or the coherence revealing what it was to kill; what it was to witness or live with those events. ${ }^{43}$

The scale of the operation was too large for Collins's intelligence officers and his 'squad', his band of young and devoted gunmen, his 'twelve apostles', to do it alone. Chosen and reliable men from various battalions of the Dublin Brigade were informed throughout the previous week. ${ }^{44}$ They then had to choose reliable men to join an intelligence agent and a member of the squad who had been assigned to each particular 'job'. But most of the men involved, the men sent to do the shooting, knew nothing of spies or executions until the night before, when even then the numbers to be shot still fluctuated to an alarming extent. ${ }^{45}$ That night they were called to secret locations around the city: to Gardiner Street, to Gloucester Street, to Parnell Square. ${ }^{46}$ Some were told what was to happen, where it was to take place, and who would go with them to identify the man to be shot. But a little over twelve hours before the shooting, most of the men involved still really knew nothing of what was to be done. They had that night to think about shooting a man in cold blood; a man they knew only as a name, maybe even an assumed name at that, at a certain address somewhere in the city. Charles Dalton recalled sitting at the fire talking well into the night because, like the others, he could not sleep. 'I was wrought up, thinking of what we had to do the next morning, and I could feel that the other men were the same ${ }^{\prime 4}{ }^{47}$ Some knew where to meet, where to collect their guns and ammunition, who would wait on guard, who would patrol the stairs, who would go with the intelligence officer and the squad man to do the shooting in the room. Others knew less, just told where to go, to 'be ready for a job in the morning ... we weren't told what we were to do'. ${ }^{48}$ For most, there was no real time to prepare, no real time, the organizers might argue, for them to worry

${ }^{43}$ In this sense, the article is using similar sources and methods now emerging in the historiography of this period, most notably Fergus Campbell's Land and revolution: nationalist politics in the west of Ireland, I89I-I92I (Oxford, 2005).

45 See Charles Dalton, BMH WS 434 .

${ }^{46}$ See for example Frank Saurin, BMH WS 7I5; Jim Slattery, Ernie O'Malley notebooks, UCDA pi7b/94(I07); Patrick Lawson, BMH WS 667; Harry Colley, BMH WS i,687.

${ }^{47}$ Charles Dalton, With the Dublin brigade (London, I929), p. I04.

48 Matty MacDonald, Ernie O’Malley notebooks, UCDA pı7b/ı5(75). 
about right and wrong, about the fear of doing it and getting caught. Harry Colley recalled the proposition being put to the men in Gloucester Street thus:

It is well to place on record that Sean Russell, the $\mathrm{O} / \mathrm{C}$, explained to them that the men to be shot were members of a new secret service which the enemy had brought into this country; that many of them had great reputations as secret service men working for England during the recent war; that it was vitally necessary for the success of our fight that they be removed; that no country had scruples about shooting enemy spies in war time; that if any man had moral scruples about going on this operation he was at full liberty to withdraw and no one would think any the worse of him; that he wanted every man to be satisfied in his conscience that he could properly take part in this operation. ${ }^{49}$

Of course Seán Russell's approach made perfect sense. In the same way that there had been no point in forcing men who believed only in a fair fight into the ranks of the squad, this operation needed men whose scruples were not likely to take them unawares. ${ }^{50}$ A conscience was all very well but, from a commanding officer's point of view, it was likely to ruin the chance of the killing and to get other men captured or killed in the attempt. Jim Slattery had a slightly different recollection of whether he had much choice in the matter of taking part. He remembered the briefing the night before had two young men watching the door as a warning to anyone who considered trying to go. ${ }^{51}$ But then why should they? Headquarters had told them that they were going to kill spies and that should have been good enough for them all. It certainly was for Frank Thornton who operated happily on the basis that if IRA intelligence chose to kill then the target must have been guilty. ${ }^{\mathbf{2}}$

Some passed an uneasy night. Frank Saurin checked the location one more time. ${ }^{53}$ James Carrigan charged and recharged the battery for the car he was meant to drive. ${ }^{\mathbf{5 4}}$ Larry Nugent slept in the same bed with Eamon Fleming. Both knowing the next day would be important but neither saying more than a few words. ${ }^{55}$ Matty MacDonald knew it would be a big job so he played a game of cards and had a drink. ${ }^{56}$ Todd Andrews went to mass, played football, read a book. Apart from suffering a slight concussion at his match, and attending a meeting about the next day's killing, it was like any other given Saturday for the nineteen-year-old. He slept well, he had been to confession, he was in a state of grace like so very many more that night, all supposedly made ready for their

${ }^{49}$ Harry Colley, BMH WS I,687.

${ }^{50}$ For example Vinny Byrne recalled that 'one or two men conscientiously objected' when asked to join the squad, one stating that 'he would have no hesitation in going out to face the enemy in open battle' but not to shoot in cold-blood. Vinny Byrne, BMH WS 423 .

${ }^{51} \mathrm{Jim}$ Slattery, Ernie O’Malley notebooks, UCDA pizb/ıo9(Io8).

52 Thornton asserted that 'the fact that we, who became aware of their activities earlier on, and smashed them by one military operation on Bloody Sunday, is sufficient answer I think to those who would try to confuse the issue by suggesting that they were shot purely because they had acted in the capacity of court-martial officers on some of our comrades.' Frank Thornton, BMH WS 615.

${ }^{53}$ Frank Saurin, BMH WS 715. $\quad{ }^{54}$ James Carrigan, BMH WS 613.

${ }_{55}$ Larry Nugent, BMH WS 907.

${ }^{56}$ Matty MacDonald, Ernie O’Malley notebooks, UCDA pr7b/ı05(75). 
own deaths mixed with some sort of guarantee of forgiveness in advance. ${ }^{\mathbf{5 7}}$ It was only in the morning that Andrews began to feel unease. He was, as he said, 'unattuned to assassination'. He was 'very excited by the assignment but the prospect of killing a man in cold blood was alien to our ideas of how a war should be conducted'. ${ }^{58}$ The seventeen-year-old Charles Dalton was equally concerned. 'Outwardly we were calm and collected, even jesting with each other. But inwardly I felt that the others were as I was - palpitating with anxiety.' He described waiting to enter the house as 'the longest five minutes of my life. Or were they the shortest? I cannot tell, but they were tense and dreadful. ${ }^{59}$ It would be easy to say that Dalton wrote this partly for effect in his memoirs, as by this point he was a veteran of several other killings. Alternatively it could be taken that this was no ordinary shooting, that at least the teenager was not yet fully inured to what was about to be done. Indeed Matty MacDonald remembered that 'Charlie Dalton couldn't sleep that night of Bloody Sunday. He thought he could hear the gurgling of the officers' blood and he kept awake all night until we told him a tap was running somewhere. ${ }^{\mathbf{6 0}}$ There was still that much of the child in him that could be fooled; wanting to hear the lie because it was ever so much better than putting up with the truth.

Dalton had done most to find the information to condemn the men in the house in Pembroke Street. He had courted the maid there, got an IRA man employed as the porter; he watched until he knew that the two men he wanted slept in rooms on the third floor. The rest of the British officers in the house were lives that may or may not be taken on the day. Dalton met Paddy Flannigan at five minutes to nine as they had arranged the night before. There were brief introductions to the men Flannagan had brought along. ${ }^{\mathbf{6 1}}$ And then as Dalton explained to Ernie O’Malley:

I was with Flannagan and 2 fellows and we went up the left hand stairs to the third flight. I knew the one where Dowling and Montgomery were for the girl had told me. The other doorway was adjacent and there was a landing ... The two lads were in bed in pyjamas and Paddy Flannigan said for us and they got up rather startled and I thought this was the [time?] and I wanted the papers. They were against the wall when Paddy fired. The fellows fell and they made a gurgling sound. Said I to Paddy Flannigan 'I want to search the bloody room.' 'Get to hell out of this' said Paddy. The other fellows brought their men to the hallway. They had the men in pyjamas and they had their hands up. I was stopped by the 3 rd Bn officers. 'Who are you they asked?' 'I'm an intelligence officer', I said and here were not more than 6 or 7 in the house. The[y] were lined up. They were held up on the staircase to the cellers. I saw one hit the floor and [fall] down the stairs. Paddy Flannigan said goodbye and went up by Earlsfort Terrace. ${ }^{\mathbf{2}}$

\footnotetext{
57 Others were said to have attended mass that morning. Robert Kee, Ireland: a history (London, I995 revised edn), p. I87.

${ }^{59}$ Dalton, Dublin brigade, pp. I04-6.

60 Matty MacDonald, Ernie O'Malley notebooks, UCDA pi7b/io5(79).

61 Charles Dalton, Ernie O'Malley notebooks, UCDA pi7b/i22(22).

62 Ibid., pi $7 \mathrm{~b} / \mathrm{I} 22(22-3)$.
} 
The two lads in the pyjamas were Major C. M. C. Dowling and Captain Leonard Price. It was not Montgomery as Dalton suspected. Paddy Flannigan shot Dowling twice and Price once and Flannigan was an accurate shot. The bullets to the chest killed both. ${ }^{63}$ Colonel Hugh Ferguson Montgomery and Captain H. B. C. Keenlyside were lined up downstairs in the hall as Dalton said. Montgomery gave his name and was shot twice in the body. Keenlyside followed and was shot four times, in the arms and in the jaw. ${ }^{64}$ Montgomery was the one who later died. Colonel W.J. Woodcock was shot in the shoulder and the back but managed to climb up the stairs to his room. ${ }^{65}$ Lieutenant Murray was wounded as he came down the stairs. ${ }^{66}$ Judging even by Dalton's fevered description there was panic and confusion in Pembroke Street, especially when British officers seemed to be emerging from every door. And this was not to mention all the pushing past scratching, struggling, screaming wives. ${ }^{67}$ Dalton may have felt pity for the men later when he wrote his book, a pity which even the Dominions Office acknowledged when a call to suppress the book was voiced in I93 $^{\mathrm{I}}{ }^{\mathbf{6}}{ }^{\mathrm{B}}$ But that morning he seemed in too much of a hurry to ' get the bloody hell out of it' to feel very much else at all.

Outside II9 Lower Baggot Street, Matty MacDonald shared a joke with Jack Keating about the size of the hammer he had brought to force in the door. But the hammer was not needed. MacDonald went on:

We knocked at the front door a maid came along have a letter from the Castle will you deliver this note to Captain Bagelly a one legged man. The maid pointing and in we went in. We tapped at the door, opened it and walked in. There were 3 of us. Bagelly was in bed. Lemass, Jimmy and I. I was kind of scared. 'Captain Bagelly?' 'That's my name.' 'I suppose you know what we came for. We came for you.' He was the Judge Advocate General. 'I suppose you've come for my guns' he said. One of us, Jimmy Brennan hid it under the bed and he reached behind for it ... Slugs and a little more was our reply. 'Get up.' He was in pyjamas. Lemass and Jimmy and I fired 2 in the head from the 3 guns. I heard maids screaming afterwards but I was told she was alright. On the ground floor was Jack Foley. A fellow came out with a towel in pyjamas for a bath and Jack stuck him up and he was balls naked. Thinking he was a lodger but he was another British army officer and how we didn't know about him, we hadn't any orders about him. ${ }^{69}$

MacDonald took a camera and whatever papers he could find. An examination of the body found that Captain G. T. Baggally had been shot on the top of the head, through the left eye and twice in the chest. ${ }^{70}$

63 Summary of evidence in the case against James Greene, evidence of the medical officer, Dublin, National Library of Ireland (NLI), Michael Noyk papers, MS 36,22I/2.

64 Evidence of Captain Keenlyside, ibid. $\quad 65$ Evidence of Colonel Woodcock, ibid.

66 House of Lords Debates, $5^{\text {th }}$ series, vol. 42, 22 Nov. 1920, col. 4I8.

67 See Anon., An officer's wife, and 'Statement by Mrs Keenlyside', London NA CO 904/ı68(66).

68 Memorandum by Sir E. Harding, 6 Apr. I93I, London NA DO 35/459/9.

69 Matty MacDonald, Ernie O'Malley notebooks, UCDA pi7b/io5(75-6).

70 Summary of evidence in the case against James Boyce, Thomas Whelan, Michael J. Tobin, and James McNamara, evidence of the medical officer, King George V Hospital, NLI Michael Noyk papers, MS $36,223 / \mathrm{I}$. 
About twelve men were admitted to 92 Lower Baggot Street at the same time. William Stapleton was among the men who asked for Captain W. F. Newbury and made their way to the first floor flat.

After some hammering on the door it was opened a little. It was evident that the occupant of the room was very cautious and suspicious because he tried to close the door again, but we jammed our feet in it. We fired some shots through the door and burst our way in. The two rooms were connected by folding-doors and the British agent ran into the front room and endeavoured to barricade the door, but some of our party had broken in the door of the front room and we all went into it. He was in his pyjamas, and as he was attempting to escape by the window he was shot a number of times. One of our party on guard outside fired at him from outside. The man's wife was standing in the corner of the room and was in a terrified and hysterical condition. The operation lasted about fifteen minutes. ${ }^{71}$

Stapleton's report said really very little at all. There was plenty about doors and getting in and getting out, but no details about what happened in that room. Captain Newbury was shot seven times; his body left hanging from the window, where as Stapleton said, he had tried to escape. ${ }^{72}$ His heavily pregnant wife could only cover him with a blanket. ${ }^{73}$

Vinny Byrne asked to see Lieutenant Peter Ames and Lieutenant George Bennett at the door of 38 Upper Mount Street. The maid was obliging, pointing out the rooms where both men slept. Byrne sent Tom Ennis with some men to the back room and he went to the front parlour himself. ${ }^{74}$

As I opened the folding-doors, the officer, who was in bed, was in the act of going for his gun under his pillow. Doyle and myself dashed into the room, at the same time ordering him to put up his hands, which he did. Doyle dashed around by the side of the bed, and pulled a Colt .45 from beneath the pillow. Right behind us came Frank Saurin and he started collecting from papers etc., which was his job. I remember looking into a drawer and seeing a Sinn Fein tie there and, if I am not mistaken, photographs of the ${ }_{19} 6$ leaders. I ordered the British officer to get out of bed. He asked me what was going to happen and I replied: 'Ah, nothing.' I then ordered him to march in front of me ... I marched my officer down to the back room where the other officer was. He was standing up in the bed, facing the wall. I ordered mine to do likewise. When the two of them were together I thought to myself 'The Lord have mercy on your souls!' I then opened fire with my Peter. They both fell dead. ${ }^{75}$

Bennett was found with a small wound at the top and a larger wound at the back of the head, one on the front of the chest, three in the back and two wounds on

71 William Stapleton, BMH WS 822.

72 Ibid.; House of Lords Debates, 5th series, vol. 42, 22 Nov. I920, col. 4I7.

73 House of Lords Debates, 5th series, vol. 42, 22 Nov. I920, col. 4 I7.

74 Vinny Byrne, BMH WS 423.

75 Ibid. A 'Peter' was the nickname for a Mauser pistol. The full sobriquet was 'Peter the Painter', a reference to the main participant in the siege of Sidney Street, London, in January I9II. 
the right forearm. ${ }^{76}$ Ames had two wounds in the right armpit, one in the right upper arm, one to the front and one to the right side of the chest. One wound in the back and one at the back of the right leg. ${ }^{77}$ The inquest did not specify which were entry and which were exit wounds. Vinny Byrne seemed to be enjoying himself which is perhaps why he left his intelligence officer behind, why this account is so very much at odds with other versions of events. ${ }^{78}$ Frank Saurin claimed he did the talking at the front door, not Byrne. ${ }^{79}$ Tom Ennis was said to have shot one of the officers. And he did so as the man still lay beside his wife in bed. ${ }^{80}$

Tom Keogh, Jim Slattery, Frank Teeling, Denis Begley, and Andy Monaghan went into 22 Lower Mount Street looking for Lieutenant H. McMahon. ${ }^{81}$ They found the man, whose real name was Angliss, in bed with the man who became the inquest's relatively notorious ' $\mathrm{Mr} \mathrm{C}$ '. He testified at Teeling's court-martial that

I was awakened about 9 a.m. by someone shouting 'Hands up' when I opened my eyes I saw five men standing at the end of my bed covering me with revolvers. One of the men who appeared to be acting as leader gave the order to keep McMahon and myself covered and he proceeded to search the room. He picked up a civilian coat belonging to McMahon and said 'is this your coat McMahon', McMahon said 'No.' He then put his hand in the inside pocket, took out a wallet and said 'You're a damned liar' and put the wallet in his pocket. He then said 'where are your guns Mac'. McMahon said 'look here we are two $\mathrm{R}$ [oman] C[atholic]s but the guns are in that bag'. The man then walked over to the bag which was lying in a corner of the room, lifted it on to the table and burst the locks off with his hands and took out three revolvers. They were one service Colt, one Webly-Scott Automatic and one .32 automatic. He put them in his pockets. I then heard firing which seemed to come from the street and I heard a noise as if someone was trying to smash in the front door. A man's voice on the landing then shouted 'are you all right there boys. They're surrounding the house.' The five men in the room then turned as if to rush out, they went a little way down the room then halted and the man who had been doing the searching raised his revolver - pointed it at the bed and fired. I saw McMahon raise his arm to cover his face and at the same time I threw myself out of the bed on to the floor practically simultaneously I heard other shots ring out from the other men in the room and they all rushed out of the room. ${ }^{82}$

McMahon was shot three times in the chest and once in the buttock. ${ }^{83}$ The officer in the next room barricaded his door. Seventeen shots failed to penetrate it

76 Summary of evidence in the case against Patrick Moran and Joseph Rochford, evidence of the medical officer, King George V Hospital, NLI Michael Noyk papers, MS 36,224/ I. $\quad{ }^{77}$ Ibid.

78 Vinny Byrne, BMH WS 423; Frank Saurin, BMH WS 7I5. $\quad{ }^{79}$ Frank Saurin, BMH WS 7I5.

${ }^{80}$ Michael Hopkinson, The Irish War of Independence (Dublin, 2004), p. 90.

81 Report by Denis Begley, NLI Michael Collins's papers, A/o532 Group VIII; Jim Slattery, Ernie O’Malley notebooks, UCDA pizb/94(Io8).

${ }^{82}$ Summary of evidence in the case of Frank Teeling, evidence of the second witness for the prosecution, NLI Michael Noyk papers, MS $36,222(3)$.

${ }^{83}$ Evidence of the seventh witness for the prosecution, Royal Army Medical Corps officer, ibid. 
and he was saved. ${ }^{84}$ Outside some passing Auxiliaries had been alerted by the screaming of the maids. Two of their number, Temporary Cadets F. Carniss and C. A. Morris, were sent to Beggar's Bush barracks for reinforcements. But they were met by some of the IRA guards posted around the house, brought to the garden of $\mathrm{I} 6$ Northumberland Road and shot. ${ }^{85}$ Both men were shot through the head but Carniss was also shot through the chest. The officer who found them testified 'I saw wounds in their heads which must have been fired at close range as their hair and skin was burnt. ${ }^{86}$ After a brief exchange of fire, in which Teeling was shot, all the rest escaped from Lower Mount Street, but not before Tom Keogh stopped to make a date with one of the maids. ${ }^{87}$ Denis Begley's account was a little different from Mr C's. C. was after all considered a 'drunkard and a coward if not worse ... suffering from shell-shock and neurasthenia'. There was talk of an illegitimate child with the maid downstairs. ${ }^{88}$ Begley's version was much simpler. Tom Keogh uttered 'Carry on lads' and McMahon was shot dead. ${ }^{89}$

A ten-year-old boy opened the door at in7 Morehampton Road. His father, Thomas Smith, owned the house. Smith's wife stated at the military inquiry:

I saw some men coming up the stairs, who appeared to number about 20, with revolvers in their hands. They then told me to put my hands up and my husband came out on the landing and asked for a little time to put on some clothes, which they granted. I then asked if I could go into my baby in the next room and they pushed me roughly into it. I then heard about 8 shots. A minute or two later I heard John Caldow (who was staying with us) call out Kate (meaning his sister) run for the doctor. I then came out and saw John Caldow in [the] entrance to the room, lying on his back wounded. I passed him and saw my husband lying very badly wounded and Mr MacClean dead. My husband had no regular occupation and owned property. His age was 47 . He did not take part in politics, but was very friendly with Captain MacClean who had just resigned from the army. ${ }^{\mathbf{9 0}}$

Caldow survived; Smith died later from the wounds to his chin, chest, buttock, and hip. ${ }^{91}$ These men were shot in a spare room at the front of the house when MacClean begged not to be killed in front of his wife. ${ }^{\mathbf{9 2}}$

The maid from 28 Earlsfort Terrace answered a ring at the door. A man asked for Mr Fitzpatrick and she replied there was no Fitzpatrick living here, just a Captain John Fitzgerald and would the two men like to see him. Four more

\footnotetext{
${ }^{84}$ House of Lords Debates, 5th series, vol. 42, 22 Nov. 1920, col. 4I5.

85 Proceedings of a court of inquiry in lieu of inquest on Temp. Cadet F. Carniss and Temp. Cadet C. A. Morris, London NA WO $35 /$ I59B.

86 Summary of evidence in the case against Frank Teeling, evidence of D.I. 2 RIC Auxiliary Division, NLI Michael Noyk papers, MS 36,222/(3). $\quad{ }^{87}$ Paddy Daly, BMH WS 387.

${ }^{88}$ Review of the case by G.G.W., I6 Feb. I920, London NA CO 904/43 34282.

89 Extract from report by Denis Begley, NLI Michael Collins's papers, A/o532 Group VIII. Begley's account states that Teeling was not in the room at the time of the shooting.

${ }^{90}$ Proceedings of a court of inquiry in lieu of inquest on Mr Thomas Herbert Smith, evidence by Mrs Smith, London NA WO 35/159B.

91 Evidence by R. F. Bridges, Captain Royal Army Medical Corps (RAMC), ibid.

92 House of Lords Debates, 5th series, vol. 42, 22 Nov. I920, col. 4 I 6.
} 
men joined them from the pavement and entered the house, three going up to Fitzgerald's room. She testified: 'I next heard Capt. Fitzgerald scream and three shots in quick succession. The party then left the house and walked away quietly. ${ }^{93}$ Fitzgerald was shot through the forehead, in the right wrist where he tried to shield himself, in the chest, and in the neck. ${ }^{94} \mathrm{He}$ was twenty-two years old and someone had already tried to kill him in Co. Clare. ${ }^{95}$

In his bedroom in the Gresham Hotel, Captain P. McCormack was having breakfast in bed and reading The Irish Field. He was shot through the head, in the neck, in the wrist, and in the groin. The racing paper was still in his hand; the blankets were singed from the closeness of the firing. ${ }^{96}$ On the next floor Mr Leonard Wilde was found lying face down on the floor of his room. The medical examiner noted that he "was lying in a pool of blood and there was part of his brain lying in front of his head'. There was another bullet in the back of his right leg. His only other testimony was that the dead man seemed well nourished and appeared to be about thirty-five ${ }^{97}$ The Times described Wilde as an innocent victim, publishing one of his letters to Arthur Henderson, secretary of the Labour party, asking how this simple 'Roman Catholic' could best consecrate his life to Labour's 'magnificent fight for real democracy' in Ireland.$^{98}$ Others said he was an adventurer, a relative of Oscar Wilde. ${ }^{99}$ Archbishop Clune told the manager of the Gresham Hotel that he was nothing but a British spy who had been thrown out of Spain. ${ }^{100}$ The men who shot him did not seem to care.

In Fitzwilliam Square Captain Crawford's wife appealed to the men who seemed intent on shooting her husband. She convinced them that he was not the Major O'Callaghan they required. Before they left one man warned 'you bloody well clear out of this country in 20 hours, or we will do for you tomorrow night'. ${ }^{101}$ Joe McGuinness was among the men who entered the Eastwood Hotel in Leeson Street only to find the two men they wanted had already gone. ${ }^{102}$ Seán Smith's appointment with four officers at the Standard Hotel in Harcourt Street was called off, never kept. There was no longer anyone there to kill. ${ }^{103}$ Patrick Lawson was told to go 'to some house in Phibsboro', but when Sunday came another order arrived telling him not to go. ${ }^{104}$ In the Shelbourne Hotel one man shot his own reflection in a mirror on the staircase. The British soldier overhead

93 Proceedings of a court of inquiry in lieu of inquest on Capt. J. J. Fitzgerald, evidence of the maid, London NA WO 35 / 159 B. 94 Evidence of Captain R. F. Bridges, RAMC, ibid.

${ }^{95}$ Evidence of Captain Fitzgerald's mother, ibid.

96 Proceedings of a court of inquiry in lieu of inquest on Captain P. McCormick (sic)] and Mr L. A. Wilde, London NA WO 35/159B.

97 Evidence of the medical examiner, ibid. $\quad 98$ Times, 23 Nov. I920.

99 Leon Ó Broin, No man's man: a biographical memoir of Joseph Brennan-civil servant and first governor of the central bank (Dublin, I982), p. 88.

100 James Doyle, BMH WS 77. Clune, the archbishop of Perth, and uncle of Conor Clune who was killed on Bloody Sunday evening, initiated unsuccessful peace talks in December I920.

101 Times, 22 Nov. I920. 102 Joe McGuinness, BMH WS 607.

103 Seán Smith, Ernie O’Malley notebooks, UCDA pi7b/ı22(I7).

104 Patrick Lawson, BMH WS 667. 
heard the commotion and fled. ${ }^{105} \mathrm{~A}$ Mr Cleevden, who boarded in a house near St Stephen's Green, was lucky enough not to have returned the night before. ${ }^{106}$ When a porter in a hotel in Exchequer Street would not give the room numbers to match the wanted names in the hotel register, the IRA thought about shooting every man in the place. ${ }^{107}$ And there were other attempts, unmentioned or unconfirmed. Todd Andrews found a woman in Captain Noble's bed in a flat in Ranelagh, half-naked and alone. He could not decide whether he felt 'glad or sorry' that Noble had not been there. ${ }^{108}$ In this he was not alone. By half past nine there were many wondering if they were glad or sorry about their part in this morning's bloody work.

\section{I}

The killings affected these men in many different ways. Charles Dalton wrote in his memoir that when it was over 'I started to run. I could no longer control my overpowering need to run, to fly, to leave far behind me those threatening streets.' Later he 'thought over our morning's work, and offered up a prayer for the fallen'. ${ }^{109}$ Matty MacDonald told Ernie O'Malley that 'Charlie Dalton was very nervous. We went to the Capitol [Theatre] to ease his mind. '110 'I got the wind up rightly' was all Dalton admitted when O'Malley asked. ${ }^{111}$ Yet for one who was blooded in the ways of the squad, for one who was so afraid himself, Dalton made no allowance for those who had never been asked to kill or see killing like this before. He complained that 'in some instances the excuses put forward for the non-carrying out of instructions were not considered very satisfactory; in particular, those received from the Commandant of the ist Battalion regarding two addresses they should have visited on the North Circular Road'. ${ }^{112}$ Todd Andrews knew all about this kind of suspicion. 'I felt that, short of actual death, I would be unable to persuade my comrades in the Company or in the Battalion that I had not faked an accident to avoid the mission. This, of course, was nonsense but I felt that I could not live with myself if I failed for any reason to turn up. ${ }^{113}$ Some men in K Company of the 3 rd Battalion quickly began to regret that they had. Larry Nugent found it difficult to get any information about what had happened on Bloody Sunday from any of them. 'The men would not talk. Three men of K Company never returned to duty after the operation. ${ }^{114}$ Twice in his Bureau statement Nugent stated that 'the men did not like this operation, but orders were orders and had to be obeyed'. ${ }^{115}$ It was 'outside the ordinary scope of the soldier' and some reacted to the pressure better than others. ${ }^{116}$ Unsteady nerves and shaking beginner's hands explained why so many

\footnotetext{
105 Gleeson, Bloody Sunday, p. I28. ${ }^{106}$ Ibid., p. I4I. $\quad{ }^{107}$ Laurence Nugent, BMH WS 907.

108 Andrews, Dublin made me, p. I53. $\quad 109$ Dalton, Dublin brigade, pp. Io6, Io8.

110 Matty MacDonald, Ernie O'Malley notebooks, UCDA pizb/ı5(79).

111 Charles Dalton, Ernie O'Malley notebooks, UCDA pi7b/i22(23).

112 Charles Dalton, BMH WS 434. $\quad{ }^{113}$ Andrews, Dublin made me, p. I52.

114 Larry Nugent, BMH WS 907. $\quad{ }^{115}$ Ibid. $\quad{ }^{116}$ Frank Thornton, BMH WS 6I5.
} 
of the wounded survived. ${ }^{117}$ Even the dead were sometimes shot in unusual places, in parts of the body where a wound would never kill. The shootings were by nature often hurried and frenetic; the likelihood of failure was high. But in Upper Mount Street one man had to have his gun taken away because his hand shook too much to fire. ${ }^{118}$

Others of course were exhilarated about the thought of their first kill, and were overheard discussing it as they rushed from the scene. ${ }^{119}$ Joe McGuinness was so frustrated that the man he was meant to shoot was not at home that he threw his gun in the canal. ${ }^{120}$ Some just seemed to admire what others had done:

Jimmy Doyle was the coolest man you ever saw. It appears that Jimmy was on guard on a landing. He was a quiet Wicklow man, quiet and always smiling. There was a mirror on the landing and two of the British intelligence men came sneaking down when they heard the racket to grab Jimmy, but he didn't seem to be taking any precautions and just as they came close to him, he shot the two of them. ${ }^{121}$

There was a growing admiration for those who could shoot and shoot well. Pat McCrea was proud that he had driven a car for one of the killings in Baggot Street. But his wife, under the impression that he had been fishing, put him out of the house when he joked about how plentiful the morning's catch had been. He spent Bloody Sunday night in St Ann's Park, but he still could not fathom why she was so perturbed. ${ }^{122}$ He possibly no longer knew how to be. He needed someone to be outraged on his behalf.

Todd Andrews was certainly outraged with the behaviour of the men from the squad that day. 'There were only women and children in the rest of the house but that did not prevent the pair from the squad behaving like Black and Tans. ${ }^{123}$ Joe Dolan started a fire, whether by intention or accident, which took the rest of the men a half an hour to put out. ${ }^{124}$ What Andrews failed to mention in his book was that Joe Dolan beat the half-naked woman who was in Captain Noble's bed and stole all of her rings. ${ }^{125}$ Naturally Dolan remained silent about it in his Bureau statement too. But then Joe Dolan had shot the porter of the Wicklow Hotel one morning and then went back there in the afternoon to eat his lunch. ${ }^{126}$ The men of the squad had learned to be more callous types. Their training was brutal and short, as Vinny Byrne explained: 'First of all, the men selected for squad work were brought on a few jobs and shown how they were carried out; secondly, each man had to prove his mettle, and was detailed to do an actual job' himself. ${ }^{127}$ Each member of the squad then killed, in what Joe Leonard called

117 Charles Townshend, The British campaign in Ireland I9I9-I92I (Oxford, I975), p. I29; Anon., An officer's wife, p. 7I. $\quad{ }^{118}$ Anon., An officer's wife, p. 7I. $\quad{ }^{119}$ Edward Kelliher, BMH WS 477.

120 Seán Smith, Ernie O’Malley notebooks, UCDA pi7b/i22(i7).

121 Matty MacDonald, Ernie O’Malley notebooks, UCDA pi7b/io5(79).

122 Pat McCrea, BMH WS 4 I3 $;$ idem, Ernie O’Malley notebooks, UCDA pi7b/i Io(I4-I5).

${ }^{123}$ Andrews, Dublin made me, p. I53. ${ }^{124}$ Ibid.

125 Charles Dalton, Ernie O'Malley notebooks, UCDA pi7b/i22(23).

126 Tim Pat Coogan, Michael Collins: a biography (London, I99o), p. I34; Joe Dolan, BMH WS 663.

127 Vinny Byrne, BMH WS 423. 
strict rotation. ${ }^{128}$ They quickly became proud of being known as an elite, as paid, young, full-time gunmen, they enjoyed being feared in London as ' gangs of tough youngsters', as 'wild young men'. ${ }^{129}$ Obsessive to the point of being fetishistic about revolvers, they had their favourite weapons and squabbled between killings about who was the best shot, about which was better, the Webley, the Mauser, or the Colt. There were 'staunch supporters' of the Peter the Painter, a lighter Mauser that was easier to conceal under your clothes. ${ }^{130}$ Charles Dalton had a holster made for himself, a holster made out of a mail sack, but a holster none the less. ${ }^{131}$ 'Tom Keogh', it was said, 'never moved without his gun. ${ }^{132} \mathrm{He}$ was dead by the age of twenty-three. They all carried $.45 \mathrm{~s}$ not $.38 \mathrm{~s}$. It had taken Detective Inspector Smith, the first detective to be assassinated in July I919, two weeks to die from his wounds from a $.3^{8}$ so a .45 would be the weapon of choice after that. ${ }^{133}$ They always brought a revolver as well as an automatic - the revolver in case the automatic ever stuck like they had learned that it did many times on the Germans during the war. ${ }^{134}$ Many of them were still teenagers when they were asked to join with consciences more likely to overlook things older men might not condone. Mick White ate one of the dead men's breakfasts on Bloody Sunday morning. ${ }^{135}$ Vinny Byrne recorded how he enjoyed 'plugging' British soldiers but he still filled his pockets with liquorice like any child would when he took part in a raid of the B\&I stores. ${ }^{136}$ Byrne was nineteen when he went to that house in Upper Mount Street on Bloody Sunday morning. It was noted with astonishment 'how quickly and with what devotion these young men got down to their jobs. Anything they lacked in age and experience, they made up in enthusiasm. ${ }^{137}$ These men may have had a conscience but, as one commentator in Blackwood's magazine put it, they had certainly come to terms with it. ${ }^{138}$ Byrne may have had qualms about being put in charge of older, more experienced men like Tom Ennis on Bloody Sunday morning, but he could only feel pity for the 'old' medical officer sent with him who did not know what to do with a gun. ${ }^{139}$

We were all young, twenty, twenty-one. We never thought we'd win or lose. We just wanted to have a go. We'd go out in pairs, walk up to the target and do it, then split. You wouldn't be nervous while you'd be waiting to plug him, but you'd imagine everyone

\footnotetext{
128 Joe Leonard, BMH WS 547.

129 Richard Lloyd George, Lloyd George (London, I960), p. 200; letter from C. S. Markbreiter to Sir Harry Batterbee, I4 Apr. I93I, London NA DO 35/459/9.

${ }^{130}$ Bernard Byrne, BMH WS 631; Paddy Daly, BMH WS 387.

131 Charles Dalton, Ernie O'Malley notebooks, UCDA pi7b/i22(20).

${ }^{132}$ Harry Colley, Ernie O'Malley notebooks, UCDA pı $7 \mathrm{~b} / 97(36)$.

${ }^{133}$ See for example Jim Slattery, Ernie O'Malley notebooks, UCDA pipb/94(Io6) and pi7b/ Iog(Io3); Jim Slattery, BMH WS. 445.

135 James Mackay, Michael Collins a life (Edinburgh, I997 edn), p. I79.

136 Interview with Kee, Ireland: a history; Vinny Byrne, BMH WS 423.

137 Eamon Broy, BMH WS i,280.

138 'Ignotus', 'Irish realities', Blackwood's Magazine, 207, Mar. I920, pp. $347-52$, at p. 349.

139 Vinny Byrne BMH WS 423.
} 
was looking into your face ... It was up to you to see that it was done however you went about it. ${ }^{140}$

For Joe Dolan, it was a simple matter: 'We had to learn to kill in cold blood and we got used to it. ${ }^{141}$ It is difficult to read statements from men like Byrne and Dolan and Leonard and so many others without concluding that these men took pleasure from the one thing that they had become very good at. In this they were no different from the men who enjoyed killing in the Great War, the Second World War, and Vietnam. ${ }^{142}$ The instincts and emotions were the same even though the scale and the circumstances of the conflict were so different. Byrne said, 'It was the joy of my life when I was handed a .45 revolver and six rounds. ${ }^{143}$ And it was a joy some of them never learned to replace.

For others the killing took its toll. Liam Tobin had a nervous breakdown before Bloody Sunday could be carried out as he planned. ${ }^{144} \mathrm{He}$ had become, according to David Neligan, 'gaunt, cynical, with tragic eyes, he looked like a man who had seen the inside of hell'. ${ }^{145}$ Bernard Byrne spoke of the agony of the drivers who had time to think in their cars of what was being done; he mentioned three who 'became nerve cases as a result of their work' ${ }^{146}$ Others turned to drink to make things bearable enough. When he was released after the Truce, Eamon Broy was 'disagreeably surprised to see many fine and highly strung young Irish Volunteers, who had been teetotallers when I last met them, drinking whiskey neat. It was bound to have a bad effect on them especially after the long struggle they had endured. ${ }^{147}$ Harry Colley confirmed this, admitting that 'there was heavy drinking in Dublin. Charlie Dalton never drank till the truce. Reaction from strain. ${ }^{148}$ George White went further and suggested that by April 192I there were serious breaches of discipline in the squad because of drink, that Collins wanted to replace Tom Keogh with the abstemious Paddy Daly. 'The attitude of HQ Squad was definitely disobedient and they cut up rather rough. ${ }^{149}$ White is supported by a series of letters dating from the previous month from the O/C Fingal. He complained of a disturbance at a dance held in the hall in Portrane asylum. When five men, led by Joe Dolan, refused to leave they were bundled into a padded cell. For the twenty minutes they were inside they slashed at the walls and door with knives. Michael Lynch wrote to Headquarters because, as he said,

if the newspapers got hold of it a grave scandal [would ensue] ... I make this report not to bring trouble on the heads of the men concerned (who are all attached to the staff of the $\mathrm{D}[\mathrm{i}] \mathrm{r}[\mathrm{ector}] /$ Intell[igence]) but because I believe they were more than drunk. They

\footnotetext{
140 Ibid. 141 Quoted in Younger, Ireland's civil war, pp. I I4-I5.

142 Bourke, An intimate history of killing. $\quad{ }^{143}$ Quoted in Younger, Ireland's civil war, pp. I I4-I5.

144 Charles Dalton, Ernie O'Malley notebooks, UCDA pizb/r22(22).

145 David Neligan, The spy in the castle (London, I968), p. 7I ; Coogan, Michael Collins, p. 77.

146 Bernard Byrne, BMH WS 63I. $\quad{ }^{147}$ Eamon Broy, BMH WS I,280.

148 Harry Colley, Ernie O'Malley notebooks UCDA pi7b/97(5).

149 George White, BMH WS 956.
} 
were stark mad for at least $\frac{1}{2}$ hour. I candidly believe that the present strains on their nerves is too much for them and has left them in such a condition that the taste of whiskey leaves them violent lunatics, and would strongly urge - after watching them for about three hours - that they be given a rest from all arduous duty. ${ }^{\mathbf{1 5 0}}$

The hospital attendants were blamed in an 'attempt to cloak up the whole affair' and Dolan continued as before. ${ }^{151}$ Three years later Major General Russell reported to the army inquiry in May I924 that 'the very nature of their work' before the truce 'left [these men] anything but normal ... if such a disease as shell-shock existed in the IRA ... the first place to look for it would be amongst these men' ${ }^{152}$ From the end of the year before the new Free State government was already worried enough to keep note of how many army men were involved in serious crimes. ${ }^{153}$ The record of events in Oriel House, the actions of the Dublin Brigade in Kerry during the civil war, the fact that Collins himself thought of sending many of his squad away, seems to suggest that many of these men, like Frank Teeling, no longer knew how to stop. ${ }^{154}$

These things, of course, are said of others, never said by a man about himself. Dalton spoke of Tobin's nerves $;{ }^{155}$ Colley told of Dalton's drinking; ${ }^{156}$ Thornton admitted that Mick McDonnell's health collapsed and he was sent by Collins to California. ${ }^{157}$ You only told someone else's secrets. There were censored and uncensored versions of events. Those who spoke to Ernie O’Malley tended to be more frank with him than in their retelling to the Bureau of Military History. With O'Malley one could, after all, debate which bullets were best for going through a policeman's 'steel waistcoat' ${ }^{158}$ But even with O'Malley certain things remain missing. For instance, there is no blood. Indeed the only participant to mention it was Mrs Woodcock, who fought with her husband's orderly on Bloody Sunday night about whether salt or Lux soap was the best way to remove the blood stains from her clothes. ${ }^{159}$ The amount of blood in the rooms at the Gresham Hotel was said to be particularly shocking. J. P. Swindlehurst, a British soldier who had seen his share of the Great War's horrors, was appalled by the 'walls and carpets bespattered with blood'. ${ }^{160}$ These men were killers who remembered the colour of a carpet on a stairs, who recalled which side of the

\footnotetext{
150 Michael Lynch (?), O/C Fingal to adjutant general, 29 Mar. I92 I, Dublin NA Dáil Éireann (DE) 2/5I7 Portrane Asylum - Incident at dance I92 I. $\quad{ }^{151}$ Memo by Seán Ó M, ibid.

${ }_{152}$ Evidence of Major General Russell before the army inquiry, Io May I924, UCDA Richard Mulcahy papers, p7/c/29; O'Halpin, Defending Ireland, p. II.

${ }^{153}$ Home Affairs returns of serious crime in Ireland with particular reference to responsibility of members of the army, July-Dec. I923, Dublin NA D/T s3527.

154 Gerry McCarthy, 'Rebel Hart', Sunday Times - Culture, I I Jan. 2004. Oriel House was headquarters of the new state's Criminal Investigation Department, and was staffed by many of the squad members and intelligence officers from the I9I9-2I period who were fiercely loyal to Collins.

155 Charles Dalton, Ernie O'Malley notebooks, UCDA pi $7 \mathrm{~b} / \mathrm{i} 22(22)$.

156 Harry Colley, Ernie O'Malley notebooks, UCDA pi $7 \mathrm{~b} / 97(5)$.

157 Frank Thornton, BMH WS 6i5. See also Bernard Byrne, BMH WS 63i.

158 Ned Broy, Ernie O’Malley notebooks, UCDA pizb/98(20). ${ }^{159}$ Anon, An officer's wife, p. 68.

${ }^{160}$ Diary of J. P. Swindlehurst, I6 Jan. I92 I, Imperial War Museum (IWM), P538.
} 
street they walked on on their way, but they never mentioned any blood. ${ }^{161}$ Nothing, not even the practicalities of whether they needed to clean their own clothes.

The women are also gone. William Stapleton was the only one to mention a wife. He admitted that she was hysterical, but he did not say that she threw herself in front of her husband's killers, that she was heavily pregnant at the time. ${ }^{162}$ The women on Bloody Sunday morning seemed to somehow disappear. What women there are were ones that could be disapproved of; these men seemed as, Lionel Curtis suggested, to disapprove of infidelity more than murder. ${ }^{163}$ It was alright to talk about a girl who was 'had' by a British spy in a flat, that was an altogether different affair, ${ }^{164}$ but thoughts of a wife fighting for her husband's life made it seem so much worse. Wives made it all seem so very cruel and squalid indeed.

John Horgan suggested that Bloody Sunday was the one day that many old IRA men 'fell silently defensive about'; that Seán Lemass cut short an unwanted inquiry about his actions with the 'curt observation that "firing squads don't have reunions" ". ${ }^{165}$ Paddy Kennedy's widow did not want her husband's name mentioned in Ernie O'Malley's notes of that day. ${ }^{166}$ Kennedy had been involved in the shooting of Captain McCormack, whom most now believe was not a spy. Captain McCormack's mother wrote to Richard Mulcahy in I922 asking if someone would admit that the shooting of her son was a mistake. She did not want people thinking he was a traitor; she was related to Michael Davitt after all. ${ }^{167}$ Somewhere in the middle of these silences and concerns about what should and should not be said, the men who did the killing seem very lost indeed. There were those who seemed to know that it was dreadful, those who rationalized it by repeating words about the justice and necessity of eliminating spies. Others just enjoyed 'this wonderful day' ${ }^{\prime 68}$ and only regretted that Dick McKee and Peadar Clancy's arrest 'knocked all the good out of it ... we had no sense of jubilation as the enemy had evened up on us'. ${ }^{169}$ But this day was not part of what many expected war of any kind to be like. As Todd Andrews admitted, 'killing a man in cold blood was alien to our ideas of how a war should be conducted'. ${ }^{170} \mathrm{He}$ had grown up imbibing fair play from the pages of The Magnet and The Gem, and the British and French army manuals that influenced many IRA training camps never mentioned war like this. ${ }^{171}$ Nothing

\footnotetext{
161 See for example Charles Dalton, Ernie O’Malley notebooks, UCDA pı 7 b/ı22; Dalton, Dublin brigade, p. I05. 162 William Stapleton, BMH WS 822.

163 Lional Curtis, Ireland (Belfast, 2002 edn), p. 59.

164 Charles Dalton, Ernie O’Malley notebooks, UCDA pi7b/i22(21).

165 John Horgan, Seán Lemass: the enigmatic patriot (Dublin, I997), p. I7.

166 Charles Dalton, Ernie O'Malley notebooks, UCDA pizb/i22(23).

167 Copy of letter from Kate MacCormack to Richard Mulcahy, 23 Mar. I922, NLI Michael Collins's papers, A/0535X.

168 Letter by Fr Dominic to unknown, 26 Nov. I920, IWM General Strickland papers, $\mathrm{P}_{3} 63$, no. 39-42. $\quad{ }^{169}$ Liam Tobin, Ernie O’Malley notebooks, UCDA pi7b/94(II2).

${ }^{170}$ Andrews, Dublin made me, p. I5 5 . $\quad{ }^{171}$ Ibid., p. 60.
} 
prepared these men for what they were about to do. In many of the statements there is a sense of knowing that it was wrong, that there was something in it that was just not fair. War was about ambushes, a fair fight; it was not supposed to be about killing a man in his bed. But to admit this, to admit that mistakes were made, that the wrong men were shot, could not be countenanced by some at all. The dead were all spies because murder could not be part of the founding myth of a nation, because murder could not be part of the stories that many of these men felt had to be told.

In historiographical terms, it may be simpler to think in terms of atrocities or unpleasant deeds that needed to be done, to count the dead but to keep the bodies and what was done to them at arms length. But too many of the men who fought between I9I9 and I92 I had to kill someone who was defenceless or alone for it to be as easily disposed of as that. Killing a spy may have been an order or a duty, but there was much to reconcile when all you saw was a man in his pyjamas clinging to his wife. In the course of his war Vinny Byrne worked out his own naïve kind of solution. You prayed for the man you were about to kill, but you never said the prayer out loud. ${ }^{\mathbf{1 7 2}}$ There was a shred of humanity still in this young killer who wanted most of all to seem tough. 